\title{
The information system of the French Peatland Observation Service: Service National d'Observation Tourbières - A valuable tool to assess the impact of global changes on the hydrology and biogeochemistry of temperate peatlands through long term monitoring
}

\author{
Sébastien Gogo ${ }^{1}$ [ $\quad$ | Jean-Baptiste Paroissien ${ }^{1}$ | Fatima Laggoun-Défarge ${ }^{1}$ |
}

Jean-Marc Antoine $^{2}$ | Léonard Bernard-Jannin ${ }^{1}$ | Guillaume Bertrand ${ }^{3}$ |

Philippe Binet $^{3}$ | Stéphane Binet ${ }^{1}$ | Guillaume Bouger ${ }^{4}$ | Yohann Brossard ${ }^{5}$ |

Thierry Camboulive $^{6}$ | Jean-Pierre Caudal ${ }^{4}$ | Stéphane Chevrier ${ }^{7}$ |

Geneviève Chiapiuso $^{3}$ | Benoît D'Angelo ${ }^{7}$ | Pilar Durantez ${ }^{6}$ | Chris Flechard ${ }^{8}$ |

André-Jean Francez $^{4}$ ｜ Didier Galop ${ }^{2}$ | Laure Gandois ${ }^{6}$ ｜ Daniel Gilbert ${ }^{3}$ |

Christophe Guimbaud $^{7}$ | Louis Hinault ${ }^{1}$ | Adrien Jacotot ${ }^{1}$ | Franck Le Moing ${ }^{1}$ |

Emilie Lerigoleur $^{2}$ | Gaël Le Roux ${ }^{6}$ | Fabien Leroy ${ }^{1}$ | Alexandre Lhosmot ${ }^{3}$ |

Qian Li $^{1}$ | Elodie Machado Da Silva ${ }^{1}$ | Jean-Sébastien Moquet ${ }^{1}$ | Juanita Mora-Gomez ${ }^{1,9}$ | Laurent Perdereau ${ }^{1}$ | Thomas Rosset ${ }^{6}$ |

Marie-Laure Toussaint ${ }^{3}$

\footnotetext{
${ }^{1}$ Univiversité d'Orléans, CNRS, BRGM, ISTO, UMR 7327, Orléans, France

${ }^{2}$ GEODE UMR 5602 CNRS, Université de Toulouse, Toulouse, France

${ }^{3}$ Chrono-Environnement, Université Bourgogne Franche-Comté, Montbéliard, France

${ }^{4}$ UMR CNRS 6553 ECOBIO, Université de Rennes 1, Rennes, France

${ }^{5}$ Univiversité d'Orléans, CNRS, Observatoire de Paris, OSUC, UMS 3116, Orléans, France

${ }^{6} \mathrm{CNRS}$, Université de Toulouse Observatoire Midi-Pyrénées, Laboratoire d'écologie fonctionnelle et environnement, UMR 5245, Toulouse, France

7 Université d'Orléans, CNRS, LPC2E, UMR 7328, Orléans, France

${ }^{8}$ Institut National de la Recherche en Agriculture, Alimentation et environnement (INRAe), UMR 1069 SAS, 65 rue de Saint-Brieuc, Rennes, France ${ }^{9}$ Le Studium Loire Valley Institute for Advanced Studies, Orléans, France
}

Correspondence

Sébastien Gogo, Univiversité d'Orléans, CNRS, BRGM, ISTO, UMR 7327, Orléans, France.

Email: sebastien.gogo@univ-orleans.fr

\section{Abstract}

Mitigating and adapting to global changes requires a better understanding of the response of the Biosphere to these environmental variations. Human disturbances and their effects act in the long term (decades to centuries) and consequently, a similar time frame is needed to fully understand the hydrological and biogeochemical functioning of a natural system. To this end, the 'Centre National de la Recherche Scientifique' (CNRS) promotes and certifies long-term monitoring tools called national observation services or 'Service National d'Observation' (SNO) in a large 
range of hydrological and biogeochemical systems (e.g., cryosphere, catchments, aquifers). The SNO investigating peatlands, the SNO 'Tourbières', was certified in 2011 (https://www.sno-tourbieres.cnrs.fr/). Peatlands are mostly found in the high latitudes of the northern hemisphere and French peatlands are located in the southern part of this area. Thus, they are located in environmental conditions that will occur in northern peatlands in coming decades or centuries and can be considered as sentinels. The SNO Tourbières is composed of four peatlands: La Guette (lowland central France), Landemarais (lowland oceanic western France), Frasne (upland continental eastern France) and Bernadouze (upland southern France). Thirty target variables are monitored to study the hydrological and biogeochemical functioning of the sites. They are grouped into four datasets: hydrology, fluvial export of organic matter, greenhouse gas fluxes and meteorology/soil physics. The data from all sites follow a common processing chain from the sensors to the public repository. The raw data are stored on an FTP server. After operator or automatic processing, data are stored in a database, from which a web application extracts the data to make them available (https://data-snot.cnrs.fr/data-access/). Each year at least, an archive of each dataset is stored in Zenodo, with a digital object identifier (DOI) attribution (https://zenodo. org/communities/sno_tourbieres_data/).

\section{KEYWORDS}

data sharing, FAIR approach, peatland network, water and carbon cycle

\section{DATA BASE NAME}

Information System of the French Peatland Observation Service, 'Service National d'Observation Tourbières'.

\section{INTRODUCTION}

There is a need for long-term observation to document and understand ecosystem responses to climate change and to stimulate synergies between observation and models. Responses of the water and the carbon (C) cycles of ecosystems to anthropogenic disturbances have to be addressed in a long-term time frame. However, long-term observation data are still scarce for many ecosystems. Peatlands are wetlands that cover only $3 \%$ of continental surfaces, but that contain between 17 and 27\% of the world soil C stock (Jackson et al., 2017; Yu et al., 2010). Although peatlands function as a global $C$ sink, they have switched locally to source systems (D'Angelo et al., 2021). This can have dramatic effects on climate change as a large amount of greenhouse gases (GHG) can be released into the atmosphere, thereby generating a positive feedback on temperature increase. Furthermore, the occurrence of peatlands within a catchment area influences the water fluxes and the export of organic carbon (OC) downstream, impacting the water quality (Fenner et al., 2011). Hence, long-term monitoring of water and $C$ cycles in catchment areas containing such sentinel ecosystems is required. This is the rationale for the construction of the 'Service National d'Observation (SNO) Tourbières' (peatlands).The implementation of long term monitoring systems requires the building of an efficient information system.

The SNO Tourbières, certified by the Centre National de la Recherche Scientifique (CNRS) in 2011, is composed of four French sites that are representative of mid-latitude lowland and upland peatlands (Figure 1). As the objectives are to document and understand how temperate peatlands will respond to local and global disturbances, 30 relevant target variables (Table 1) are monitored corresponding to 5 datasets: (a) water table depth (WTD); (b) multiparameter station; (c) soil-meteorological; (d) eddy covariance (EC) fluxes and (e) chamber fluxes. The target variables are monitored with the same protocol in each site (Table 1).

The datasets of the SNO Tourbières have been used to improve knowledge of hydrological processes. Binet et al. (2013) used WTD and the soil-meteorological datasets from the La Guette site to develop a model highlighting the sensitivity of evapotranspiration to peatland plant community composition. Bertrand et al. (2021) evaluated WTD to meteorological parameters and simulated future WTD under various IPCC scenarios. Bernard-Jannin et al. (2018) used the WTD dataset from La Guette to set up a model describing the dissolved organic $C$ (DOC) concentration in peat water. They were able to identify the most relevant hydrological processes and factors determining DOC dynamics across a range of conditions at the same site. Rosset, Gandois, Le Roux, Teisserenc, Durantez Jimenez, Camboulive, and Binet (2019) and Rosset, Gandois, Le Roux, Teisserenc, Durantez Jimenez, Camboulive, and Binet (2019); Rosset, Gandois, Le Roux, Teisserenc, Durantez Jimenez, and Camboulive (2019); Rosset et al. (2020), with data from 


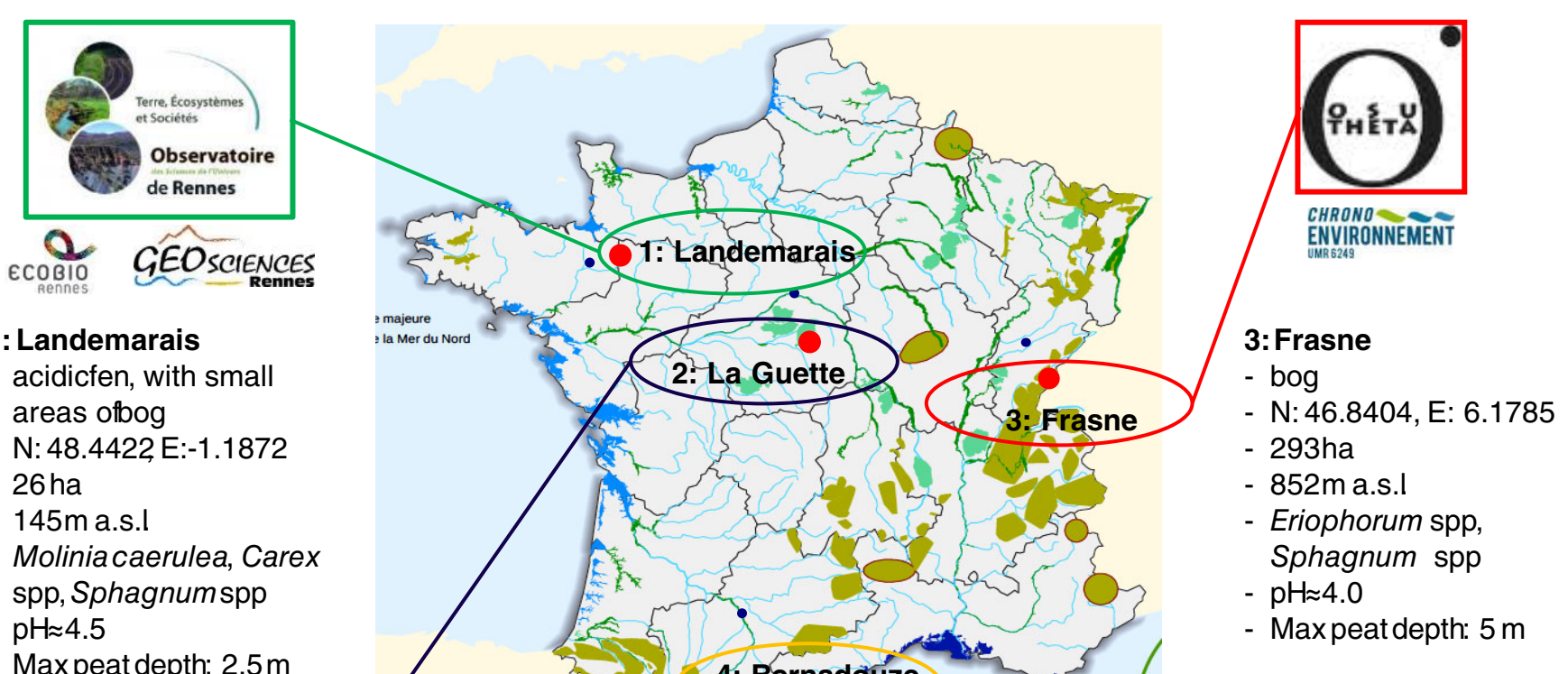

- Max peat depth: $2.5 \mathrm{~m}$

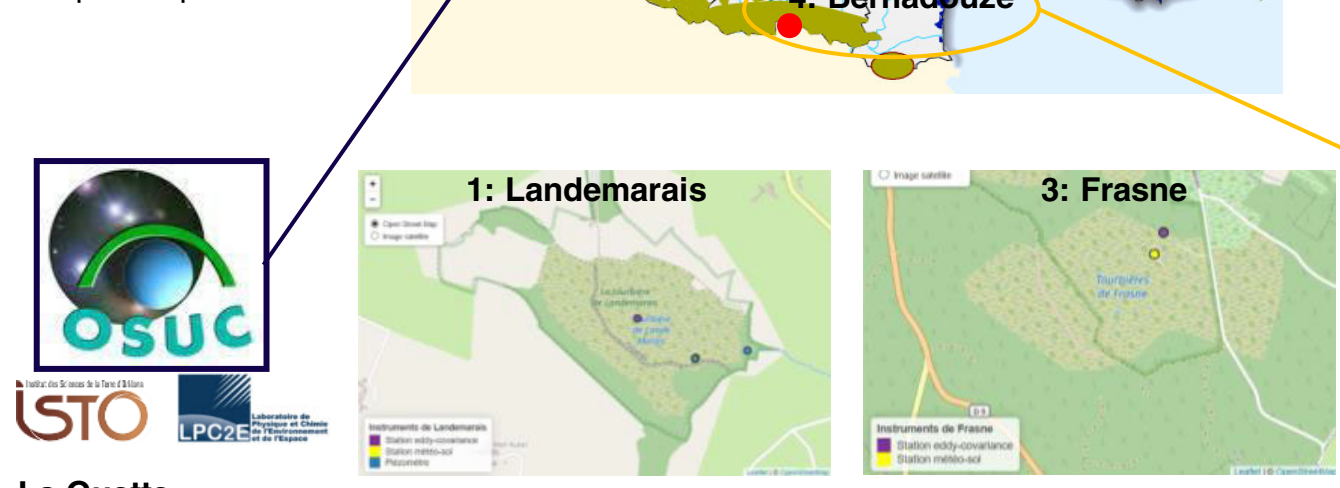

2: La Guette

- acidicfen,

- N: 47.3217, E: 2.28047

- 23 ha

- 152m a.s.l

- Molinia caerulea, ericaceousshrubs, Sphagnum spp

- $\mathrm{pH} \approx 4.5$

- Maxpeat depth: $1.8 \mathrm{~m}$

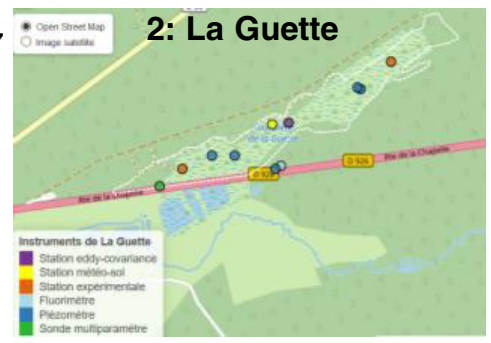

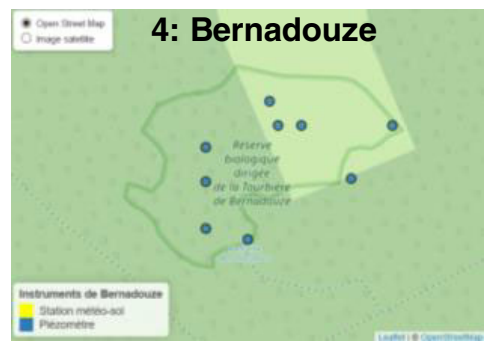

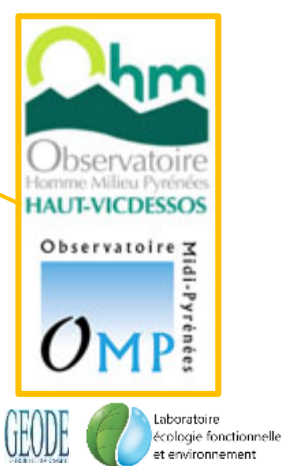

4: Bernadouze

- acidicfen, with bog lenses

- N:42.8026, E: 1.4238

- 4.7ha

- 1343m a.s.l

- Sphagnum spp, Moliniacaerulea, Carex spp

- $\mathrm{pH} \approx 4.5$

- Max peat depth: $10 \mathrm{~m}$

FIGURE 1 Locations and characteristics of the SNO Tourbières sites. Each site is associated to at least one observatory: Observatoire hommes-Milieux (OHM) and Observatoire Midi Pyrénnées (OMP) for Bernadouze, Observatoire des sciences de l'Univers (OSU) THETA for Frasne, OSU de Rennes (OSUR) for Landemarais, OSU de la région Centre (OSUC) for La Guette. All the sites are registered in the dynamic ecological information management system - site and dataset registry (DEIMS-SDR): Bernadouze - https://deims.org/708c9dcd-6757-4bb8b849-3cc5666252f2, Frasne - https://deims.org/113183a6-38f2-4ec8-94ff-8bdbd4708ea4, Landemarais - https://deims.org/368383d9-d3a14abb-9ba3-d70bf071826e, La Guette - https://deims.org/331c1b2b-2283-4396-8e8b-d9d3d040e3cd (map from: Institut Français de l'Environnement, Observatoire des Zones Humides, 2006)

the WTD and the multiparameter station (outflow rate and DOC concentration) datasets, investigated the factors influencing DOC and particulate organic carbon (POC) export. They were able to show that in a high-elevation peatland the majority of exported OC occurred in dissolved form during flood events. In the Critical Peat project, the WTD, multiparameter and EC flux datasets from Frasne were used to better understand the relationship between the underlying bedrock and the peatland water and C cycles (Lhosmot et al., 2019).

\section{I SENSOR CHARACTERISTICS AND DATA ACQUISITION}

An Orpheus Mini (OTT, pressure sensor) is used to measure the WTD in all sites (Table 1). The resolution of the sensor is $1 \mathrm{~mm}$ and its accuracy is $2 \mathrm{~mm}$. It measures the water column pressure and the atmospheric pressure. The latter is subtracted from the former to obtain the water column height. Then the distance between the soil surface 


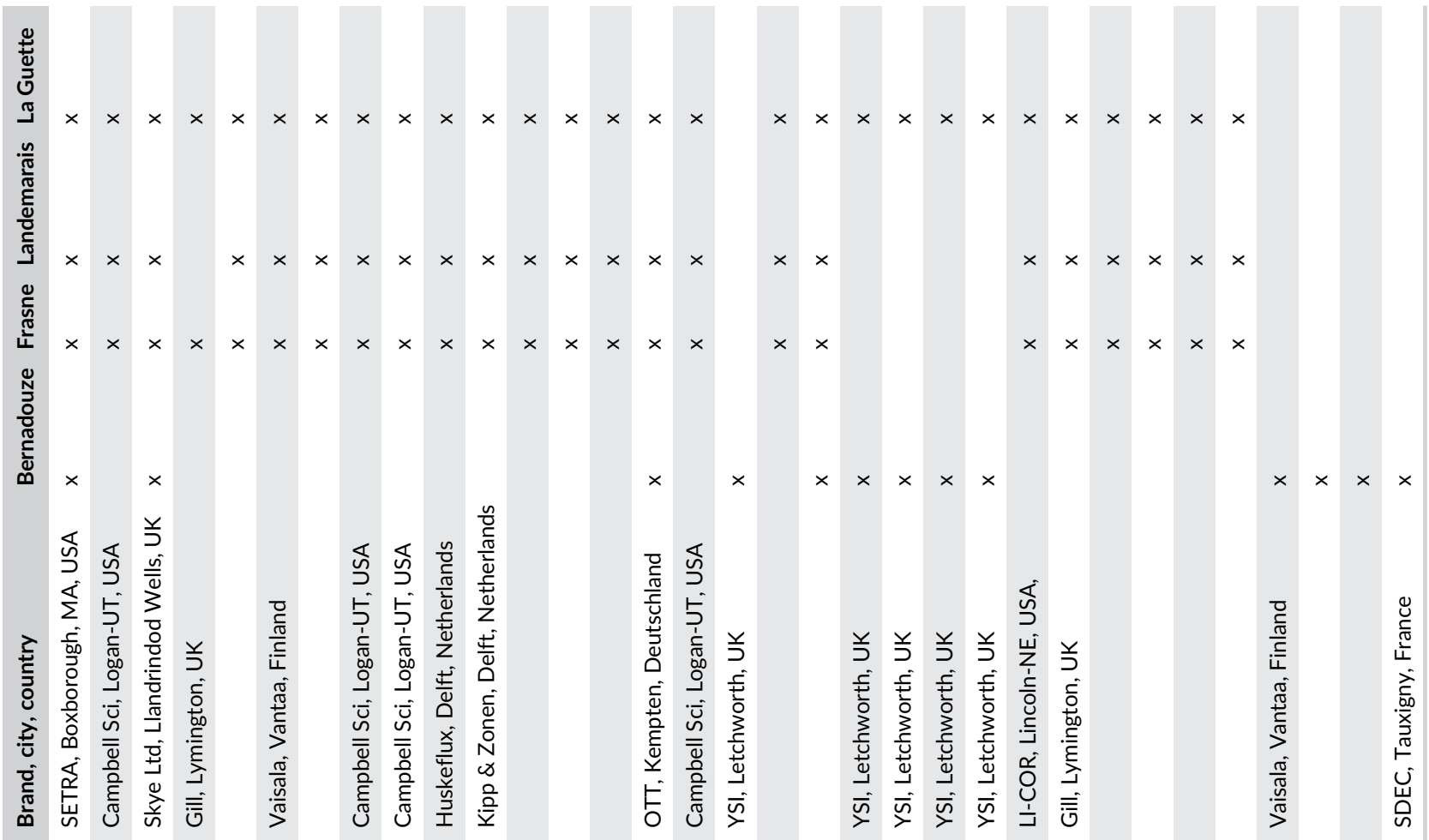

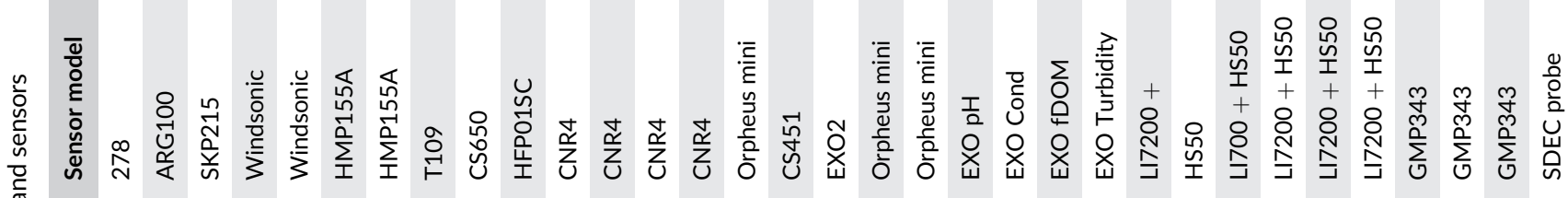

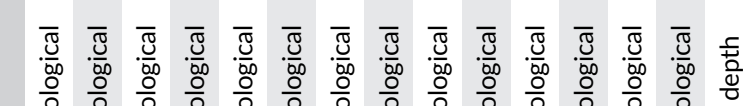

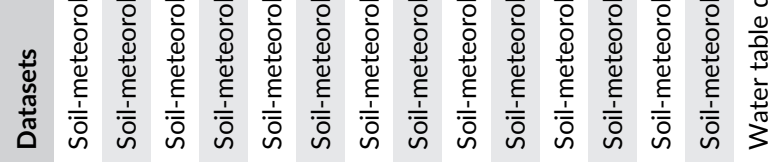

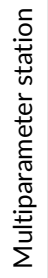

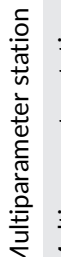

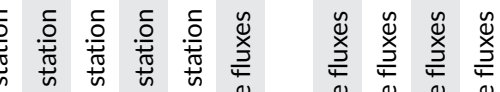

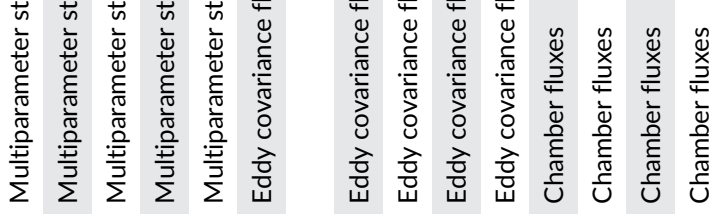

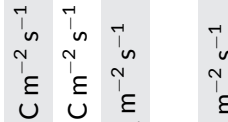

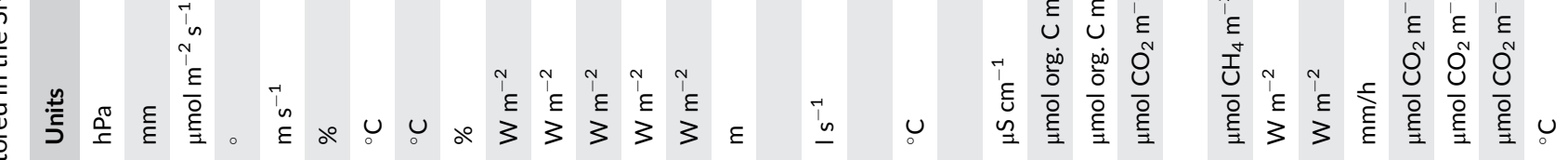

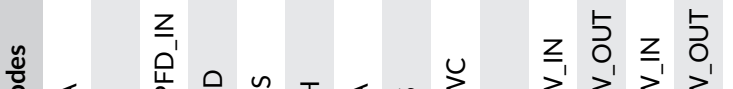

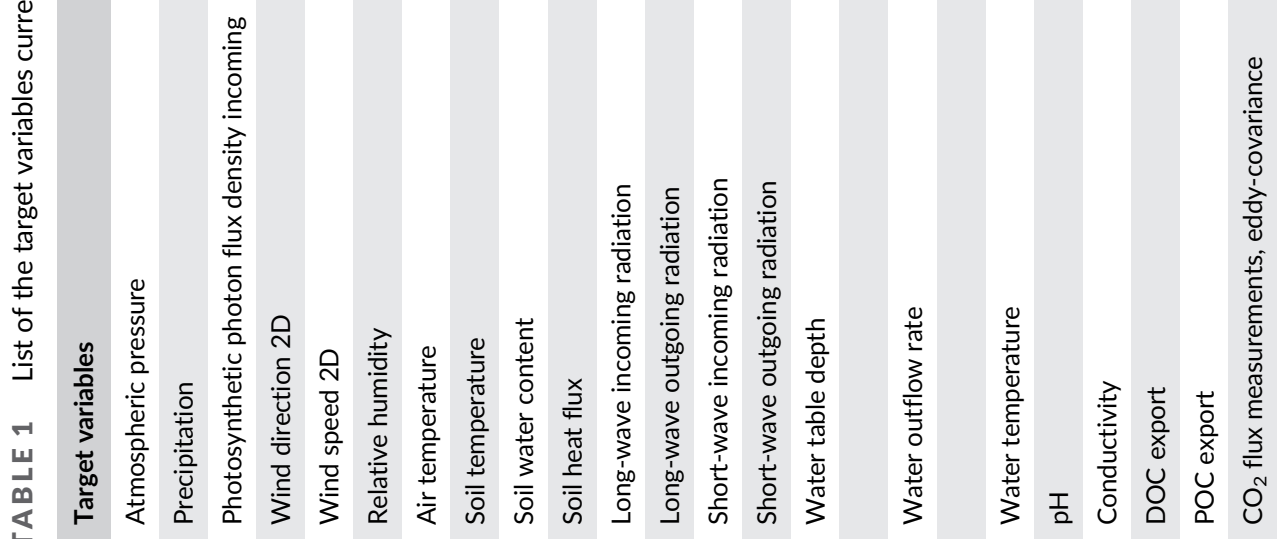

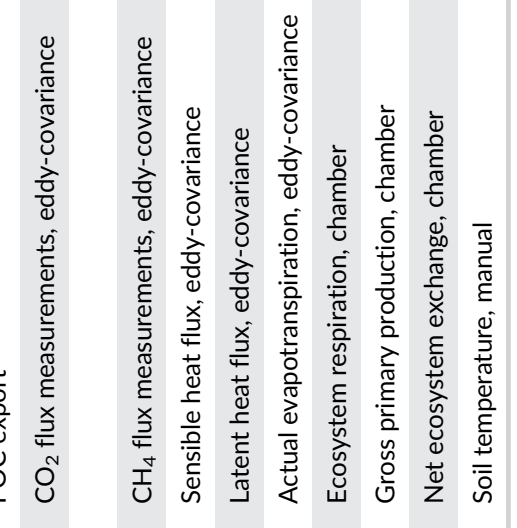


and the top of the water column is measured manually to obtain the WTD. Since this value can vary due to soil moisture changes, and snow and ice compaction, this variable is seasonally measured after the installation of the sensor and averaged over the longest period possible. This average value is then used to calibrate the whole time series.

The same sensor is also used to assess the streamflow at the outlet of the catchment containing the peatlands. The outflow intensity is proportional to the water height. At low frequency, water outflow is measured using salt dilution and the water column height is simultaneously recorded. A calibration curve relating outflow and water height is established. This curve is used to produce a high frequency outflow time series (1 recording every $30 \mathrm{~min}$ ).

Fluorescence of the dissolved organic matter (fDOM) is used as a proxy to assess the DOC concentration (Rosset, 2019a). A fraction of the total DOM flouresces. It is assumed that the total DOC is proportional to the fraction of fluorescent DOM (Rosset, 2019a). A fluorimeter (EXO fDOM) is connected to the multiparameter station (EXO2, Table 1). This optical sensor measures fluorescence at the excitation/ emission couple at $365 / 480 \mathrm{~nm}$. EXO fDOM expresses the fluorescence in quinine sulphate units (QSU) in the range of 0-300 ppb QSU, at a resolution of $0.01 \mathrm{ppb}$ QSU and with a detection limit at $0.07 \mathrm{ppb}$ QSU. The fDOM is recorded once every 30 minutes. At low frequency (once a month), water is sampled and the DOC content is assessed with a total OC analyser (infrared analyser, detection limit: $4 \mu \mathrm{g} \mathrm{I}{ }^{-1}$, measuring range $0.4 \mu \mathrm{gl}^{-1}-30 \mathrm{gl}^{-1}$ ). At the same time, the fDOM value is recorded. Then, a statistical relationship between fDOM and DOC is calculated. By applying the equation to the fDOM data, a DOC concentration time series can be estimated. Multiplying the DOC concentration by $\mathrm{Q}$ gives the DOC flux out of the peatland: FDOC.

The same principle is applied to assess POC export (FPOC), with turbidity instead of fluorescence. A turbidimeter (EXO Turbidity) is connected to the EXO2. This is an optical sensor measuring light diffusion of (near infrared, excitation at $860 \mathrm{~nm}$ ) at an angle of $90^{\circ}$. EXO Turbidity expresses the turbidity in formazin nephelometric units (FNU) in the range of $0-4000 \mathrm{FNU}$ and at a resolution of $0.1 \mathrm{FNU}$ (precision of 5\%; Rosset, 2019a). The turbidity is recorded once every $30 \mathrm{~min}$. At low frequency (once a month and during flood events), water is sampled and the POC content is assessed by filtering the water $(0.7 \mu \mathrm{m}$, glass fibre filter, GF/F, WHA1825047, Whatman), measuring the mass of suspended matter and the $C$ content of the suspended matter on the filter (elemental analyser, precision of $0.2 \%$, accuracy of $0.05 \%$ ). At the same time, the turbidity value is recorded. Then, a statistical relationship between turbidity and POC is calculated. By applying the equation to the turbidity data, a POC concentration time series is obtained. Multiplying the $\mathrm{POC}$ concentration by $Q$ gives the POC flux out of the peatland, FPOC.

The EC technique was chosen as it is the most appropriate tool to monitor evapotranspiration and surface-atmosphere $C$ fluxes (carbon dioxide and methane) over a large surface of an ecosystem (Flechard et al., 2020). The EC and soil-meteorological measurements follow the recommendations of the Integrated Carbon Observation System (ICOS, https://www.icos-cp.eu/) for level 2 stations (http://www. icos-etc.eu/icos/documents/instructions). For carbon dioxide $\left(\mathrm{CO}_{2}\right)$ and water vapour $\left(\mathrm{H}_{2} \mathrm{O}\right)$ the sensor used is the LI-COR enclosed LI7200 IRGA (infrared gas analyser). For $\mathrm{CO}_{2}$, the calibration ranges from 0 to 3000 ppm, with an accuracy within 1\% of the reading. For $\mathrm{H}_{2} \mathrm{O}$, the calibration ranges from 0 to $60 \mathrm{mmol} \mathrm{mol}^{-1}$, with an accuracy within $2 \%$ of the reading. For the methane $\left(\mathrm{CH}_{4}\right)$ concentration, the sensor model is the open-path LI7700 (measurement based on wavelength modulation spectroscopy at ambient air temperature and pressure). The calibration ranges from 0 to $40 \mathrm{ppm}$, with an accuracy within $1 \%$ of the reading. A GILL HS50 ultrasonic anemometer is used to obtain the 3D wind direction and speed. For the wind speed, the calibration ranges from 0 to $45 \mathrm{~m} \mathrm{~s}^{-1}$, with an accuracy within $1 \%$ of the reading. For the wind direction, the directional resolution is $1^{\circ}$, with an accuracy within $1 \%$ of the reading. All the gas concentrations and the wind variables are recorded at $20 \mathrm{~Hz}$. The surface exchange fluxes are calculated at a 30-minute time-step using Eddypro (open source software from LI-COR) and Rflux (developpers) software.

The chamber flux data are collected manually at low frequency (6-12 times per year) with the Vaisala CARBOCAP GMP343 (measuring range: $0-2000 \mathrm{ppm}$, precision: $\pm 5 \mathrm{ppm}+2 \%$ of the value). The chamber is $30 \mathrm{~cm}$ high with a diameter of $30 \mathrm{~cm}$, portable, and removed between measurements. The probe is inserted into the chamber and left between 2 and $5 \mathrm{~min}$. Flux is calculated from the slope of the $\mathrm{CO}_{2}$ concentration against time (D'Angelo et al., 2021).

\section{DATA FLOW}

From acquisition to accessibility, the data of the SNO Tourbières go through four stages (Figure 2): (a) collection/storage; (b) processing; (c) integration into a database; (d) dissemination. The underlying principle of the SNO Tourbières information system is the findable, accessible, interoperable, re-usable (FAIR, Wilkinson et al., 2016) approach.

1. Collection and storage. The raw data (sensor output) are stored in the FTP server 'SRV-SO' located in CNRS - Orléans (SRV = server, SO = system of observation, Figure 2). Data produced by automated stations are acquired at different frequencies, from $20 \mathrm{~Hz}(E C)$ to 1 measurement per $30 \mathrm{~min}$.

2. Processing. Each dataset undergoes a quality check and data treatment. Calculations of high frequency time series are undertaken with scripts that may require specific information, such as the relationship between water height and water flow rate at the outlet obtained manually and at a low frequency. All the information (metadata) and scripts are stored in a second file. The processed data are stored in a third file (CSV format) with a measurement frequency of 1 per $30 \mathrm{~min}$ frequency for all data sets. The data from this third file proceed to the next step (Figure 2).

3. Integration into the database. All the operators working on data processing can store their data in the database at: https://datasnot.cnrs.fr. Before uploading a data set, the operator must fill in the information required by the system to allow the data to be 


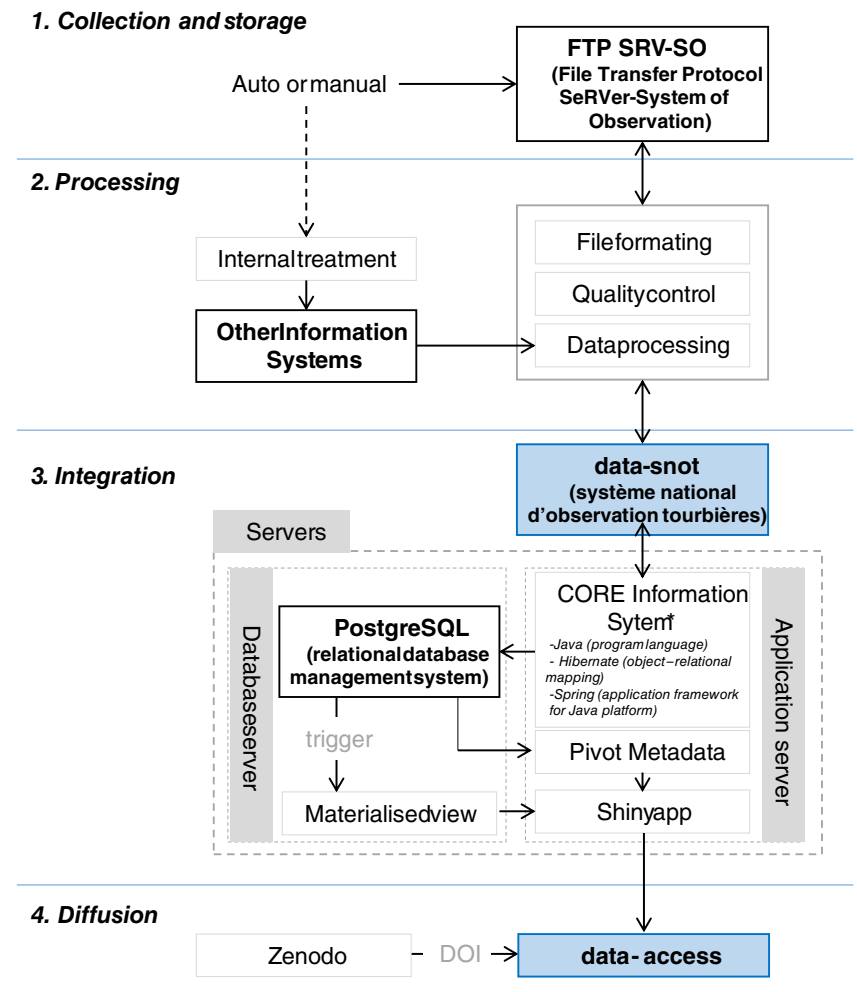

FIGURE 2 Data flow within the information system from the sensors to the public and the DOI attribution. The core information system used originated from the Service d'Observation d'Expérimentation au long term pour la recherche en environnement (SOERE, long term observation and experimental service for research on the environment)

uploaded to the database and to produce the metadata. This information is called 'reference data'. The core (database and web application) of the SNO Tourbières information system was adapted from the standard developed by the ECOINFORMATIQUE team of the Institut National de la Recherche en Agriculture, Alimentation et environnement (INRAe, InfoSol unit in Orléans). The database management system used is PostgreSQL (https://www.postgresql.org/).

4. Dissemination. The data are made accessible through web applications managed by the SNO Tourbières team and through data portals managed by research infrastructures (Observatoire de la Zone Critique Applications et Recherche: OZCAR, ICOS, FLUXNET$\mathrm{CH} 4$, see data availability section below).

\section{I FUNDING, CONTRIBUTORS AND DATA OWNERSHIP}

Recurring funding for the network coordination and some equipment is provided by the CNRS. The permanent staff cost is covered by the different universities and research institutes: CNRS, Universités d'Orléans, de Bourgogne Franche-Comté, de Rennes 1, Paul Sabatier and Jean Jaurès, INRAe. Equipment, operating costs and nonpermanent staff are funded through projects: (a) inter-regional European Union programme INTERREG: CARE-PEAT: Restoring the carbon storage capacity of peatlands (North West Europe, NWE 808), REPLIM: Red Pirenaica de Observatorios de ecosistemas vulnerables (lagos, turberas) al cambio climatico (Program Of Cooperation EspañaFrance-Andorra, POCTEFA, EFA056/15), PIRAGUA (POCTEFA, EFA210/16), OPCC (Observatoire Pyrénéen des Changements Climatiques, POCTEFA, EFA082/15); (b) State-Region Planning Agreement (Contrat Plan Etat-Région - CPER) project; (c) Agence National de la Recherche, ANR, projects: PEATWARM (ANR-07-VUL010), TRAM (ANR JCJC 15-CE01-008), Laboratoires d'Excellences, LabEx DRHIMM (Dispositif de Recherche Interdisciplinaire sur les Interactions Hommes-Milieux, 11-LABX-0010), LabEx VOLTAIRE (VOLatils - Terre, Atmosphère et Interactions - Ressources et Environnement, 10-LABX-0100) or the; (d) Region Centre-Val de Loire (PIVOTS: Plateformes d'Innovation, de Valorisation, d'Optimisation Technologiques environnementaleS, CArBioDiv: restoring peatlands to promote Carbon sequestration and BioDiversity, CarEx: Carbon sequestration through Experimentation on vegetation), Bourgogne Franche Comté (CRITICAL Peat).

S. Gogo, F. Laggoun-Défarge, G. Bertrand, A.-J. Francez, D. Galop, L Gandois, D. Gilbert contributed as data producers and/or site managers and/or network coordinators. J.-B. Paroissien, L. Perdereau Y. Brossard, J.-P. Caudal, E. Lerigoleur contributed ton the building and/or the technical set-up (in situ and/or in relation to the server) of the information system. J.-M. Antoine, L. Bernard-Jannin, P. Binet, S. Binet, G. Bouger, T. Camboulive, S. Chevrier, G. Chiapiuso, B. D'Angelo, P. Durantez, C. Fléchard, C. Guimbaud, L. Hinault, A. Jacotot, F. Le Moing, G. Le Roux, F. Leroy, A. Lhosmot, Q. Li, E. Machado Da Silva, J.-S. Moquet, J. Mora-Gomez, T. Rosset, M.-L. Toussaint participated in producing the datasets (maintenance, data retrieval, calculations, funding).

The data belong to the French State and can be used by anybody as long as the data are properly cited, either by acknowledging the SNO Tourbières and/or by citing their digital object identifier (DOI) when available. Unless otherwise stated, data from SNO-Tourbières are licensed under Creative Commons CC BY-SA 4.0.

\section{6 | INVOLVEMENT OF THE SI SNO TOURBIÈRES IN NATIONAL AND INTERNATIONAL RESEARCH INFRASTRUCTURES}

At the national level, the SNO Tourbières is part of OZCAR, the French research infrastructure (RI) on the critical zone (https://www. ozcar-ri.org/, Gaillardet et al., 2018), and is registered in the OZCAR information system, THEIA-OZCAR (https://in-situ.theia-land.fr/; Braud et al., 2020). The Bernadouze site is part of an interdisciplinary observatory Observatoire Hommes-Milieux (OHM - Laboratoire d'exellence Dispositif de Recherche Interdisciplinaire sur les Interactions Hommes-Milieux: LabEx DRIIHM). Data collected in this 
framework are available at: http://193.55.175.137:8080/ geonetwork/srv/fre/catalog.search\#/home. At the European level, La Guette peatland has been part of the French and European ICOS ecosystem network (https://www.icos-cp.eu/, Franz et al., 2018) as an associated site since November 2019. At the international level, the methane flux of La Guette peatland is part of the FLUXNET-CH4 dataset (Knox et al., 2019; Delwiche et al., in prep.).

\section{7 | DATA AVAILABILITY}

The data of the SNO Tourbières are available through a web application developed with R-Shinny: https://data-snot.cnrs.fr/data-access/ (Figure 2). A tool to produce customized figures was developed by dreamRs, a company developing data science packages in $\mathrm{R}$ language (https://www.dreamrs.fr/). All the applications used in the SNO Tourbières information system are located in the CNRS servers in Orléans.

EC fluxes and soil-meteorological data of La Guette peatland are also available through the ICOS carbon portal: https://www.icos-cp. eu/observations/carbon-portal. The $\mathrm{CH}_{4}$ fluxes of this site are available at: https://fluxnet.org/doi/FLUXNET-CH4/FR-LGt (https://doi. org/10.18140/FLX/1669641).

Attributing a DOI to a dataset ensures its correct citation and long lasting archiving. Each DOI is associated to a landing page that has to remain accessible in the long term. The strategy in the SNO Tourbières is to assign a fixed $\mathrm{DOI}$ to a dataset and apply a versioning to avoid too many landing pages. To do so, the chosen application is Zenodo (Figure 2), an open access data, research and software repository that generates a $\mathrm{DOI}$ and manages versioning. With the versioning, as soon as we have a new dataset, a new DOI is created with its associated metadata. This process makes the system flexible, traceable and manageable. The data are updated between one and three times per year. A SNO Tourbières data repository has been created: https://zenodo.org/communities/sno_tourbieres_data/. This application allows contribution from and to other data managing structures. An article can be written with a subset of data. These data can be deposited in another data repository with the reference to the article. The SNO Tourbières dataset will mention if it contains this particular sub-dataset: 'HasPart' (e.g., Rosset, 2019b; Rosset, Gandois, Le Roux, Teisserenc, Durantez Jimenez, Camboulive, \& Binet, 2019). Furthermore, datasets of the SNO Tourbières can be contained in a larger data set (e.g., Fluxnet, ICOS, OZCAR) and will mention it as: 'IsPartOf'.

\section{ACKNOWLEDGEMENTS}

The SNO Tourbières team would like to thank A. Schellenberger and P. Tcherniatinsky from the ECO-INFORMATIQUE team of the INFO SOL laboratory of the INRAe center in Orléans for their help in adapting the initial database to our requirements. We also thank V. Chaffard and C. Coussot for helping us integrate our data in the OZCAR-THEIA information system. The SNO Tourbières is coordinated by the Observatoire des Sciences de l'Univers en region Centre (OSUC - Université d'Orléans, CNRS, CNES). The SNO Tourbières is certified by the CNRS. The SNO Tourbières is part of the Research Infrastructure OZCAR (Observatoire de la Zone Critique, Application et Recherche) and one site, La Guette, is part of ICOS (Integrated Carbon Observation System) and another one, Bernadouze, is part the Observatoire Hommes-Milieux (OHM - Laboratoire d'exellence Dispositif de Recherche Interdisciplinaire sur les Interactions HommesMilieux: LabEx DRIIHM).

\section{DATA AVAILABILITY STATEMENT}

The data belong to the French State and as such can be used by anybody as long as the data are properly cited (either by acknowledging the SNO Tourbières and/or by citing their digital object identifier DOI - when available).Unless otherwise stated, data from SNOTourbières are licensed under Creative Commons CC BY-SA 4.0.

\section{ORCID}

Sébastien Gogo (D) https://orcid.org/0000-0002-0867-497X

\section{REFERENCES}

Bernard-Jannin, L., Binet, S., Gogo, S., Leroy, F., Défarge, C., Jozja, N., Zocatelli, R., Perdereau, L., \& Laggoun-Défarge, F. (2018). Hydrological control of dissolved organic carbon dynamics in a rehabilitated Sphagnum -dominated peatland: A water-table based modelling approach. Hydrology and Earth System Sciences, 22(9), 4907-4920. https://doi. org/10.5194/hess-22-4907-2018

Bertrand, G., Ponçot, A., Pohl, B., Lhosmot, A., Steinmann, M., Johannet, A., Pinel, S., Caldirak, H., Artigue, G., Binet, P., Bertrand, C., Collin, L., Magnon, G., Gilbert, D., Laggoun-Deffarge, F., \& Toussaint, M.-L. (2021). Statistical hydrology for evaluating peatland water table sensitivity to simple environmental variables and climate changes application to the mid-latitude/altitude Frasne peatland (Jura Mountains, France). Science of the Total Environment, 754, 141931. https://doi.org/10.1016/j.scitotenv.2020.141931

Binet, S., Gogo, S., \& Laggoun-Défarge, F. (2013). A water-table dependent reservoir model to investigate the effect of drought and vascular plant invasion on peatland hydrology. Journal of Hydrology, 499, 132-139. https://doi.org/10.1016/j.jhydrol.2013.06.035

Braud, I., Chaffard, V., Coussot, C., Galle, S., Juen, P., Alexandre, H., Baillion, P., Battais, A., Boudevillain, B., Branger, F., Brissebrat, G., Cailletaud, R., Cochonneau, G., Decoupes, R., Desconnets, J.-C., Dubreuil, A., Fabre, J., Gabillard, S., Gérard, M.-F., ... Squividant, H. (2020). Building the information system of the French critical zone observatories network: Theia/OZCAR-IS. Hydrological Sciences Journal, 1-19. https://doi.org/10.1080/02626667.2020.1764568

D'Angelo, B., Leroy, F., Guimbaud, C., Jacotot, A., Zocatelli, R., Gogo, S., \& Laggoun-Défarge, F. (2021). Carbon balance and spatial variability of $\mathrm{CO}_{2}$ and $\mathrm{CH}_{4}$ fluxes in a sphagnum-dominated peatland in a temperate climate. Wetlands, 41(1). https://doi.org/10.1007/s13157-02101411-y

Fenner, N., Williams, R., Toberman, H., Hughes, S., Reynolds, B., \& Freeman, C. (2011). Decomposition 'hotspots' in a rewetted peatland: Implications for water quality and carbon cycling. Hydrobiologia, 674 (1), 51-66. https://doi.org/10.1007/s10750-011-0733-1

Flechard, C. R., Ibrom, A., Skiba, U. M., de Vries, W., van Oijen, M., Cameron, D. R., Dise, N. B., Korhonen, J. F. J., Buchmann, N., Legout, A., Simpson, D., Sanz, M. J., Aubinet, M., Loustau, D., Montagnani, L., Neirynck, J., Janssens, I. A., Pihlatie, M., Kiese, R., ... Sutton, M. A. (2020). Carbon-nitrogen interactions in European forests and semi-natural vegetation - Part 1: Fluxes and budgets of carbon, nitrogen and greenhouse gases from ecosystem monitoring and 
modelling. Biogeosciences, 17(6), 1583-1620. https://doi.org/10. 5194/bg-17-1583-2020

Franz, D., Acosta, M., Altimir, N., Arriga, N., Arrouays, D., Aubinet, M., Aurela, M., Ayres, E., López-Ballesteros, A., Barbaste, M., Berveiller, D., Biraud, S., Boukir, H., Brown, T., Brümmer, C., Buchmann, N., Burba, G., Carrara, A., Cescatti, A., ... Vesala, T. (2018). Towards long-term standardised carbon and greenhouse gas observations for monitoring Europe's terrestrial ecosystems: A review. International Agrophysics, 32 (4), 439-455. https://doi.org/10.1515/intag-2017-0039

Gaillardet, J., Braud, I., Hankard, F., Anquetin, S., Bour, O., Dorfliger, N., de Dreuzy, J. R., Galle, S., Galy, C., Gogo, S., Gourcy, L., Habets, F., Laggoun, F., Longuevergne, L., Le Borgne, T., Naaim-Bouvet, F., Nord, G., Simonneaux, V., Six, D., ... Zitouna, R. (2018). OZCAR: The French network of critical zone observatories. Vadose Zone Journal, 17 (1), 180067. https://doi.org/10.2136/vzj2018.04.0067

Jackson, R. B., Lajtha, K., Crow, S. E., Hugelius, G., Kramer, M. G., \& Piñeiro, G. (2017). The ecology of soil carbon: Pools, vulnerabilities, and biotic and abiotic controls. Annual Review of Ecology, Evolution, and Systematics, 48(1), 419-445. https://doi.org/10.1146/annurevecolsys-112414-054234

Knox, S. H., Jackson, R. B., Poulter, B., McNicol, G., Fluet-Chouinard, E., Zhang, Z., Hugelius, G., Bousquet, P., Canadell, J. G., Saunois, M., Papale, D., Chu, H., Keenan, T. F., Baldocchi, D., Torn, M. S., Mammarella, I., Trotta, C., Aurela, M., Bohrer, G., ... Zona, D. (2019). FLUXNET-CH4 synthesis activity: Objectives, observations, and future directions. Bulletin of the American Meteorological Society, 100(12), 2607-2632. https://doi.org/10.1175/BAMS-D-18-0268.1

Lhosmot, A., Bertrand, G., Steinmann, M., Jacotot, A., Ponçot, A., Collin, L., Toussaint, M.-L., Gogo, S., Magnon, G., Stefani, V., Loup, C., Jeanton, H., Walter, A.-V., Bichet, V., Gilbert, D., Crini, N., Gandois, L., Denimal, S., Moquet, J.-S., ... Lavastre, V. (2019). The CRITICAL PEAT project: The importance of hydrology for carbon reactivity along with atmosphere Peatland interactions. Preliminary results from the Frasne peatland observatory. Jura Mountains. https://doi.org/10.13140/RG.2.2.34759.24480

Rosset, T. (2019a). Transfert de carbone organique des tourbières vers les eaux de surfaces: Quantification, identification des mécanismes de contrôles et détermination de l'influence des activités anthropiques locales. University of Toulouse.

Rosset, T. (2019b). High frequency biogeochemical and hydrological monitoring in two mountainous peatlands. 6 datasets

Rosset, T., Binet, S., Antoine, J.-M., Lerigoleur, E., Rigal, F., \& Gandois, L. (2020). Drivers of seasonal- and event-scale DOC dynamics at the outlet of mountainous peatlands revealed by high-frequency monitoring. Biogeosciences, 17(13), 3705-3722. https://doi.org/10.5194/bg-17-37052020

Rosset, T., Gandois, L., Le Roux, G., Teisserenc, R., Durantez Jimenez, P., \& Camboulive, T. (2019). Stream organic matter exports from a montane peatland (2015-01-01 to 2018-01-01), supplement to: Rosset, Thomas; Gandois, Laure; Le Roux, Gaël; Teisserenc, Roman; Durantez Jimenez, Pilar; Camboulive, Thierry; Binet, S (2019): Peatland contribution to stream organic carbon exports from a montane watershed. Journal of Geophysical Research: Biogeosciences, 124(11), 3448-3464. https://doi.org/10.1594/PANGAEA.899200

Rosset, T., Gandois, L., Le Roux, G., Teisserenc, R., Durantez Jimenez, P., Camboulive, T., \& Binet, S. (2019). Peatland contribution to stream organic carbon exports from a montane watershed. Journal of Geophysical Research: Biogeosciences, 124(11), 3448-3464. https://doi.org/10. 1029/2019JG005142

Wilkinson, M. D., Dumontier, M., Aalbersberg, I. J., Appleton, G., Axton, M., Baak, A., Blomberg, N., Boiten, J.-W., da Silva Santos, L. B., Bourne, P. E., Bouwman, J., Brookes, A. J., Clark, T., Crosas, M., Dillo, I., Dumon, O., Edmunds, S., Evelo, C. T., Finkers, R., ... Mons, B. (2016). The FAIR guiding principles for scientific data management and stewardship. Scientific Data, 3(1), 160018. https://doi.org/10. 1038/sdata.2016.18

Yu, Z., Loisel, J., Brosseau, D. P., Beilman, D. W., \& Hunt, S. J. (2010). Global peatland dynamics since the last glacial maximum. Geophysical Research Letters, 37(13), L13402. https://doi.org/10.1029/2010GL043584

How to cite this article: Gogo, S., Paroissien, J.-B., LaggounDéfarge, F., Antoine, J.-M., Bernard-Jannin, L., Bertrand, G., Binet, P., Binet, S., Bouger, G., Brossard, Y., Camboulive, T., Caudal, J.-P., Chevrier, S., Chiapiuso, G., D'Angelo, B., Durantez, P., Flechard, C., Francez, A.-J., Galop, D., .. Toussaint, M.-L. (2021). The information system of the French Peatland Observation Service: Service National d'Observation Tourbières - A valuable tool to assess the impact of global changes on the hydrology and biogeochemistry of temperate peatlands through long term monitoring. Hydrological Processes Part A, 35(6), e14244. https://doi.org/10.1002/hyp.14244 